\author{
235 Officers and Council \\ 240 14th Teaching and \\ Learning Conference \\ 241 APSA Strategic Plan \\ in Brief \\ 244 New Editors for \\ Journal of Political \\ Science Education \\ 246 Briefs
}

\author{
247 Next in $P S$ \\ 250 Executive Summary: \\ The Double Bind \\ 260 Translated Executive \\ Summary: La Doble \\ Disyuntiva \\ 270 Washington Insider \\ 272 APSA Members \\ of the Month
}

\title{
Meet the APSA Officers and Council
}

T he following council members and officers were approved in October 2016 by the APSA Council. APSA welcomes the new council members and other officers to APSA leadership.

\section{PRESIDENT-ELECT}

\section{Kathleen Thelen}

Kathleen Thelen is Ford Professor of Political Science at MIT. She received her BA from the University of Kansas and her PhD from the University of California, Berkeley. Thelen is a comparativist whose work focuses on the origins and evolution of political-economic institutions in the rich democracies. Her latest book, Varieties of Liberalization and the New Poli-

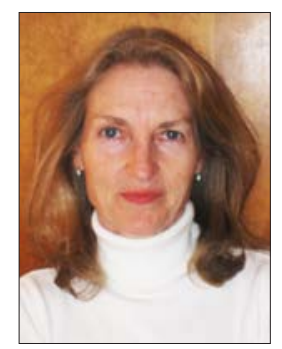
tics of Social Solidarity (2014), received the Barrington Moore Prize and was co-winner of Best Book in the European Politics and Society Section. A previous work, How Institutions Evolve, was selected for the 2006 Mattei Dogan Award, and shared the 2005 Woodrow Wilson Foundation Award. Thelen has also contributed to the literature on institutional analysis, including Advances in Comparative Historical Analysis (2015) and Explaining Institutional Change (2010), both coedited with James Mahoney, Beyond Continuity (2005, with Wolfgang Streeck) and Structuring Politics (1992, with Sven Steinmo). Her article "Historical Institutionalism in Comparative Politics" remains the most cited and most downloaded contribution to the Annual Review of Political Science. Her work has also appeared in a number of journals, including World Politics, Comparative Political Studies, and Politics \& Society, among others.

Thelen has been awarded fellowships from the Institute for Advanced Study
(Berlin), Radcliffe Institute, Oxford University, the Max-Planck-Society, and the AmericanScandinavian Foundation, among others. She is a Permanent External Scientific Member of the Max Planck Institute for the Study of Societies, and has held visiting appointments in Europe (Sweden, UK, France, Denmark) and Latin America (Mexico, Argentina). She was chair of the Council for European Studies (2002-2006) and President of the Society for the Advancement of Socio-Economics (2008-2009). Along with Erik Wibbels, she edits the Cambridge University Press Series in Comparative Politics. She is a member of the American Academy of Arts and Sciences (since 2015) and its German equivalent, the Berlin-Brandenburg Academy of Sciences (since 2009).

Thelen has been active in the association, most recently as a member of APSA Council and Treasurer. She has also served on numerous committees and as an officer in several Organized Sections-Comparative Politics (president), Politics and History (president), Qualitative and Multi-Method Research (vice-president), and European Politics and Society (treasurer).

\section{VICE PRESIDENTS}

\section{Elaine C. Kamarck}

Elaine C. Kamarck is a senior fellow in the Governance Studies Program and the director of the Center for Effective Public Management at the Brookings Institution.

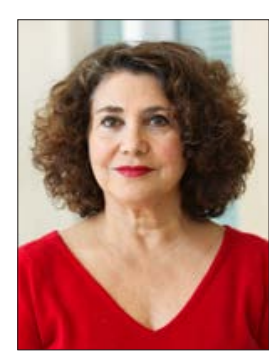

She is also a lecturer in public policy at the Harvard Kennedy School of Government. Kamarck is an expert on government innovation and reform in the United States, OECD countries, and developing countries. In addition, she also focuses her research on the presidential nomination system and American politics and has worked in many American presidential campaigns. Kamarck is the author of Primary Politics: Everything You Need to Know about How America Nominates Its Presidential Candidates $2^{\text {nd }} E d$. (Brookings Institution Press, 2016). She is also the author of How Change Happens: The Politics of US Public Policy (Lynne Rienner Publishers, 2013) and The End of Government...As We Know It (Lynne Rienner Publishers, 2007). She served in the Clinton administration as a senior advisor to the vice president where she ran the National Performance Review, also known as the "reinventing government initiative." She has been a member of the Democratic National Committee and the DNC's Rules Committee since 1997. She has participated actively in four presidential campaigns and in ten nominating conventions-including two Republican conventions.

\section{Ian Shapiro}

Ian Shapiro is Sterling Professor of Political Science at Yale University, where he also serves as Henry R. Luce Director of the MacMillan Center for International

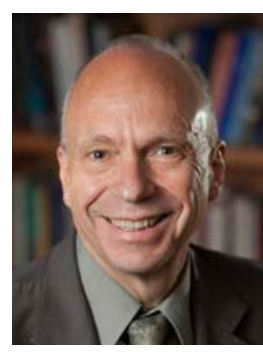
and Area Studies. He has written widely and influentially on democracy, justice, and the methods of social inquiry. A native of South Africa, he received his JD from the Yale Law School and his PhD from the Yale political science department, where he has taught since 1984 and served as chair from 1999 to 2004. Shapiro is a fellow of the American Academy of Arts and Sciences and the American Philosophical Society, and a member of the Council on Foreign Relations. He is a past fellow of the Carnegie Corporation, the Guggenheim 
Foundation, and the Center for Advanced Study in the Behavioral Sciences. Shapiro has held visiting appointments at the University of Cape Town, The University of Oslo, Sciences Po in Paris, Keio University in Tokyo, and Nuffield College, Oxford. Recently, his articles have appeared in the American Political Science Review, the Journal of Politics, and elsewhere. His new book, Politics Against Domination, was published by Harvard University Press in 2016. Shapiro's current research concerns the relations between democracy and the distribution of income and wealth.

\section{Janet M. Box-Steffensmeier}

Janet M. Box-Steffensmeier is Vernal Riffe Professor of Political Science and professor of sociology by courtesy at Ohio State University (PhD, University of Texas, 1993.)

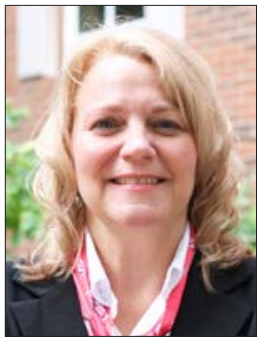

She directs the Program in Statistics and Methodology (PRISM) at Ohio State University. She has served as the faculty representative to the Ohio State Board of Trustees in 2013 and as the divisional dean for social and behavioral sciences starting in 2014. Box-Steffensmeier served as president of the Midwest Political Science Association and the Political Methodology Society as well as treasurer of APSA. She has twice received the Gosnell Award for the best work in political methodology and the Emerging Scholar Award of the Elections, Public Opinion, and Voting Behavior Organized Section in 2001. She was an inaugural fellow of the Society for Political Methodology. The BoxSteffensmeier Graduate Student Award, given annually by the Interuniversity Consortium for Political and Social Research (ICPSR) is named after her in recognition of her contributions in political methodology and her support of women in this field. She helped found the Visions in Methodology (VIM) Conferences for women in political methodology as well. She received a Distinguished Teaching Award from the political science department in 2013, Distinguished Undergraduate Mentor Award from Ohio State University in 2009, Warren E. Miller Award for Meritorious Service to the Social Sciences from ICPSR in 2013, Ohio State University Distinguished Scholar award in 2012, Political Methodology Career Achievement Award in 2013, and Women's Caucus for the Midwest Political Science Association's Outstanding Professional Achievement for Scholarship and Mentorship in 2016.

Her work focuses on campaigns and elections, Congress, and lobbying as well as event history, time series, and network methodologies. She was a coeditor of The Oxford Handbook of Political Methodology, which provides comprehensive overviews and critiques of both quantitative and qualitative methodologies.

\section{TREASURER}

\section{Marion Orr}

Marion Orr is the Frederick Lippitt Professor of Public Policy and professor of political science and urban studies at Brown University. Orr is the former director of the

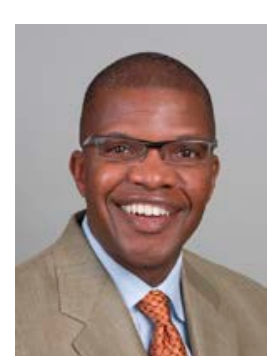

A. Alfred Taubman Center for Public Policy at Brown. He is also a former chair of Brown's political science department.

He is the author and editor of seven books, including Black Social Capital: The Politics of School Reform in Baltimore (University Press of Kansas), which won the Policy Studies Organization's Aaron Wildavsky Award for the best book published in 1999, and The Color of School Reform:Race, Politics and the Challenge of Urban Education (Princeton University Press), which was named the best book in 1999 by the American Political Science Association's Urban Politics Section.

His research focuses on American politics with a focus on African American politics, urban politics, the politics of urban schools, and community organizing. Orr is currently writing the first scholarly a biography of Charles C. Diggs, Jr., Michigan's first black congressman.

Orr has held a number of fellowships, including an appointment as research fellow at the Brookings Institution, a presidential fellowship from the University of California, Berkeley, and a fellowship from the Ford Foundation.

Orr has been active in the APSA. He served as a member of the APSA's Executive Council from 2003 to 2005 . He served as president of the APSA's Urban Politics Organized Section. In addition, he has served on numerous APSA committees, including the Committee on Education and Professional Development, APSA Strategic Planning
Committee, Ralph Bunche Book Award Committee, Siting and Engagement Committee, and the Hubert H. Humphrey Award Committee.

Orr is also active and served in leadership roles in other academic societies. From 2000 to 2006 he was an elected member of the Governing Board of the Urban Affairs Association (UAA), an international organization devoted to the study of urban issues. In 2005-2006 he served as chair of UAA's Governing Board. Orr has also served as a member of the executive council of the National Conference of Black Political Scientists. He has served, or is currently serving, on the editorial boards of the Journal of Urban Affairs, Educational Evaluation and Policy Analysis, and Urban Affairs Review.

\section{COUNCIL}

\section{Matt A. Barreto}

Matt A. Barreto is cofounder and managing partner of the polling and research firm Latino Decisions which he cofounded with Gary Segura in 2007. Barreto is also profes-

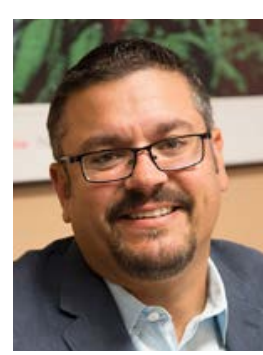
sor of political science and Chicana/o studies at University of California, Los Angeles (UCLA). In 2012 Time Magazine called Latino Decisions the "goldstandard in Latino American polling," and Barreto's research was recognized in the 30 Latinos who made the 2012 election by Politic365. He was listed in the Top 100 Global Thinkers of 2012 by the European Politics Magazine LDSP and was named one of the top 15 leading Latino pundits by Huffington Post, which said Barreto was "the pollster that has his finger on the pulse of the Latino electorate." In 2015 Barreto was hired by the Hillary Clinton presidential campaign to run polling and focus groups on Latino voters.

In 2010 Barreto implemented the first ever weekly tracking poll of Latino voters during the 2010 election, which Latino Decisions continued in 2012. Working closely with Segura, he has also overseen large multistate election eve polls, battleground tracking polls, extensive message testing research, and countless focus groups. He has been invited to brief the US Senate, the White House, and congressional committees, and has been a keynote speaker at many of the major Hispanic association conferences including NALEO, LULAC, CHCI, NCLR, and others. 
He received his $\mathrm{PhD}$ in political science from the University of California, Irvine. Barreto has published more than 40 scholarly research articles and book chapters that examine Latino public opinion, voting behavior, and race politics more generally in America. He is also the author of the two books, Ethnic Cues: The Role of Shared Ethnicity in Latino Political Behavior (University of Michigan Press, 2010) as well as Change They Can't Believe In: The Tea Party and Reactionary Politics in America (Princeton University Press, 2013). He just completed his third book, Latino America, coauthored with Segura, on the growth and influence of Latino voters 2008-2012 presidential elections (Public Affairs Press).

In 2008, Barreto was a co-principal investigator (with Gary Segura) of the American National Election Study Latino oversample, which included the first ever Spanish language translation of the ANES and the first ever oversample of Latino voters. In 2009, he was appointed to the ANES Board of Overseers.

\section{Christina Wolbrecht}

Christina Wolbrecht is associate professor of political science and director of the Rooney Center for the Study of American Democracy at the University of Notre Dame. She received her $\mathrm{PhD}$ from Washington University in St. Louis.

Wolbrecht's areas

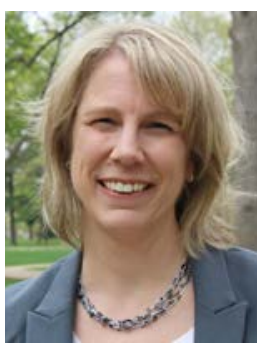

of expertise include

American politics, political parties, gender and politics, and American political development. She is the coauthor, with J. Kevin Corder, of Counting Women's Ballots: Female Voters from Suffrage through the New Deal (Cambridge 2016), a project supported by the National Science Foundation. She also is the author of The Politics of Women's Rights: Parties, Positions, and Change (Princeton 2000), which received the 2001 Leon D. Epstein Outstanding Book Award from the Political Organizations and Parties Organized Section of APSA. Wolbrecht's work on party position-taking, women as political role models, the representation of women, and support for political institutions has appeared in journals including Perspectives on Politics, American Journal of Political Science, Journal of Politics, and Legislative Studies Quarterly. She has coedited books on the American political parties, women as political actors, and democratic inclusion. Wolbrecht is a coeditor of Cambridge Studies in Gender and Politics for Cambridge University Press, and serves or has served on the editorial boards of the American Journal of Political Science, Journal of Politics, Legislative Studies Quarterly, and Politics \& Gender. She has been active in the discipline, chairing or serving on a number of APSA, MPSA, and SPSA committees and caucuses. Wolbrecht is an editorial board member of the \#WomenAlsoKnowStuff initiative.

\section{Colleen J. Shogan}

Colleen J. Shogan is the deputy director of National and International Outreach at the Library of Congress and an adjunct assistant professor of government at George-

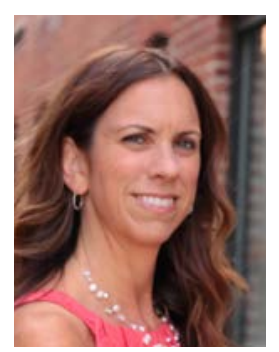
town University. At the Library, she supervises programs such as the Center for the Book, National Library Services for the Blind and Physically Handicapped, the National Book Festival, the Publishing Office, the Federal Research Division, the Kluge Center for Scholars, exhibits, visitor services, and K-12 Educational Outreach.

She holds a PhD from Yale University in political science and a BA from Boston College. At Yale, she was a National Science Foundation graduate fellow. Her intellectual interests include American political development, the presidency, Congress, and political rhetoric. Her recent research has focused on congressional social media usage. At Georgetown, she teaches a graduate seminar on APD.

She previously served as the deputy director at the Congressional Research Service (CRS) and as a Senate policy staffer. She came to Capitol Hill through the Congressional Fellowship Program as the William E. Steiger Fellow. In the $112^{\text {th }}$ Congress, Colleen participated in the Stennis Fellows Program.

Before working in Congress, Shogan was an assistant professor at George Mason University. Her first book, The Moral Rhetoric of American Presidents, was published by Texas A\&M University Press. She has also published articles in Perspectives on Politics, Polity, PS: Political Science \& Politics, Studies in American Political Development, Presidential Studies Quarterly, Rhetoric \& Public Affairs, Women $\mathcal{E}$ Politics, White House Studies, Online Information Review, and Social Movement Studies.
Shogan is a past president of the National Capitol Area Political Science Association and serves on the board of directors for the Presidency and Executive Politics research group and the advisory panel for the Beryl Radin Pracademic Fellowship. She is a member in good standing of the Cosmos Club. Colleen is also a mystery writer and has published two novels set on Capitol Hill with Camel Press.

\section{Juliet Hooker}

Juliet Hooker is associate professor of government and of African and African Diaspora studies at the University of Texas, Austin. She is a political theorist whose

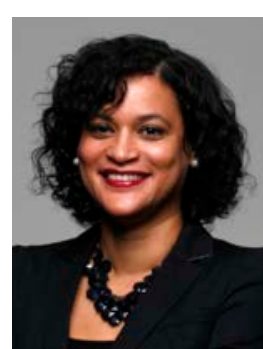
primary research interests include comparative political theory and critical race theory, particularly black political thought, Latin American political thought, political solidarity, and multiculturalism; she has also published on Afro-descendant and indigenous politics and multicultural rights in Latin America. Hooker is the author of Race and the Politics of Solidarity (Oxford University Press, 2009), and has a forthcoming book Theorizing Race in the Americas: An Intellectual Genealogy (Oxford, 2016) that juxtaposes four prominent US African-American and Latin American thinkers: Douglass, Sarmiento, Du Bois, and Vasconcelos. Her work has been supported by the National Endowment for the Humanities, and has appeared in such journals as the American Political Science Review, Political Theory, Politics, Groups and Identities, Souls, Journal of Latin American Studies, and Latin American Research Review. Hooker recently served as cochair of the APSA Presidential Task Force on Racial and Social Class Inequalities in the Americas (2014-2015), and as associate director of the Teresa Lozano Long Institute of Latin American Studies at UT-Austin from 2009 to 2014. She is an editorial board member of the National Political Science Review journal of the National Conference of Black Political Scientists. Within APSA she has served on the Okin-Young Award and First Book Award Committees of the Foundations of Political Theory Organized Section. Hooker is an award-winning teacher, and has held visiting fellowships at the CUNY Graduate Center, the Du Bois Institute for African 
American Research at Harvard University, and the Kellogg Institute for International Studies at Notre Dame.

\section{Kristian Skrede Gleditsch}

Kristian Skrede Gleditsch is professor, department of government, University of Essex and research associate, Peace Research Institute Oslo. He has a PhD

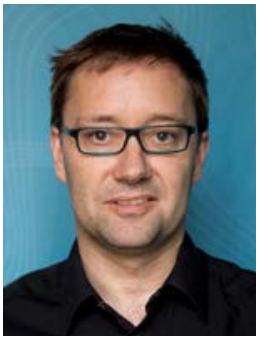

in political science from the University of Colorado. His research interest includes conflict and cooperation, democratization, political geography, political methodology, and data development.

He is the author of Inequality, Grievances, and Civil War (Cambridge University Press, 2013, with Lars-Erik Cederman and Halvard Buhaug), Spatial Regression Models (Sage 2008, with Michael D. Ward), All International Political is Local: The Diffusion of Conflict, Integration, and Democratization (University of Michigan Press, 2002), and articles in numerous journals including the American Journal of Political Science, American Political Science Review, International Organization, International Studies Quarterly, Journal of Conflict Resolution, Journal of Peace Research, Journal of Politics, Political Analysis, and World Politics.

His research has received several awards, including the 2014 Conflict Processes Organized Section best book award, the 2012 Heinz I. Eulau best article award and the 2000 Helen Dwight Reid dissertation award from APSA, and the 2007 Karl Deutsch Award from the International Studies Association. He has received grants from the Alexander von Humboldt Foundation, European Research Council, National Science Foundation, and the Research Council of Norway.

Gleditsch is head of the APSA Conflict Processes Organized Section 2014-2016 and chairs an APSA dissertation award committee for 2016. He has also been a vice president of the International Studies Association (2014-2015) and chaired its Committee on Professional Rights and Responsibilities (2014-2016). He has served as coeditor for Research and Politics (2015-2016) and the British Journal of Political Science (2010-2013) and is a member of several editorial boards.

\section{Mark Crescenzi}

Mark Crescenzi is a Bowman and Gordon Gray Term Professor of Political Science at the University of North Carolina,

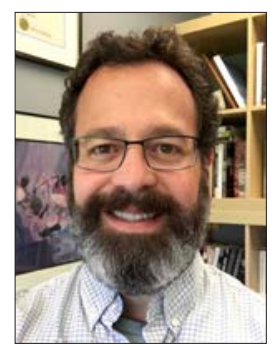

Chapel Hill (UNC)

$\mathrm{He}$ received is $\mathrm{BA}$ from the University of California, Irvine, and his $\mathrm{MA}$ and $\mathrm{PhD}$ from the University of Illinois, UrbanaChampaign. $\mathrm{He}$ has been teaching at UNC since 1999.

His research centers on the study of peace and conflict processes, with a focus on the effects of reputation on conflict, cooperation, and coordination; the link between regime dynamics and violence within and between states; and the role of economics in interstate conflict. His research has appeared in journals such as the American Journal of Political Science, Conflict Management and Peace Science, International Studies Quarterly, International Theory, the Journal of Conflict Resolution, the Journal of Peace Research, and the Journal of Politics. He published a book with Lexington Press in 2005 on economic interdependence and international conflict, and his research has been supported by the National Science Foundation. He teaches undergraduate and graduate courses in international relations, the causes of conflict in world politics, and conflict management and resolution.

Crescenzi served as section president of the Conflict Processes Organized Section from 2010 to 2012, and has served on the section's council. In 2015-2016, he also served on the Committee to Rename the Helen Dwight Reid Award. In addition to his work with APSA, he has been active in the International Studies Association, Midwest Political Science Association, and Peace Science Society, and has served on the editorial boards of the American Journal of Political Science, International Studies Quarterly, and the Journal of Politics.

\section{Omar G. Encarnación}

Omar G. Encarnación is professor of political studies at Bard College, where he teaches comparative politics and Latin American and Iberian studies. His research focuses on the causes and consequences of transi-

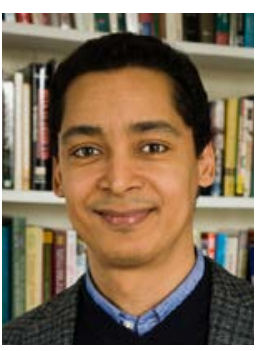
tions to democracy, the role of civil society in the process of democratization, and the policy choices that new democracies make to cope with a difficult and painful past. He is the author of four books, including, Democracy without Justice in Spain: The Politics of Forgetting (University of Pennsylvania Press, 2014) and Out in the Periphery: Latin America's Gay Rights Revolution (Oxford University Press, 2016), and more than a dozen peer-reviewed articles and reviews published in Comparative Politics, Political Science Quarterly, Comparative Political Studies, International Studies Quarterly, Journal of Democracy, Mediterranean Quarterly, West European Politics, Acta Politica, Human Rights Quarterly, Perspectives on Politics, Ethics \& International Affairs, South European Society and Politics, and Studies in Comparative International Development. His political commentary appears in The New York Times, Foreign Affairs, The Wilson Quarterly, Current History, Orbis, Global Dialogue, World Policy Journal, The Irish Times, and World Politics Review.

Encarnación received his $\mathrm{PhD}$ from the department of politics of Princeton University, and taught at Sarah Lawrence College prior to coming to Bard. While at Princeton, he was the recipient of numerous awards and fellowships, including Princeton University's Presidential Fellowship, the Council for European Studies Pre-dissertation Fellowship, and a Fulbright Dissertation Fellowship to Spain. Since completing the $\mathrm{PhD}$, he has been awarded a Ford Foundation Post-doctoral Fellowship and research grants from the Spanish Ministry of Culture and the National Research Council, and has been named a visiting fellow at the Center for Advanced Studies in the Social Sciences of the Juan March Institute in Madrid, Georgetown University's Center for Latin American Studies, the Carnegie Endowment for International Peace in Washington, DC, and the political science department of New York University. He has worked as a consultant for the US State Department, the World Bank, and Freedom House. Past service for APSA includes cofounding the Iberian politics group and serving as program chair for the comparative democratization section.

\section{Renée Bukovchik Van Vechten}

Renée Bukovchik Van Vechten is an associate professor of political science at the University of Redlands. She earned a BA in political science from the University of San Diego and a PhD from the University of California, Irvine. Van Vechten's political science research examines legislative processes and behavior, including the impacts of political reforms such as term limits. Her work on state-level politics and policy is 


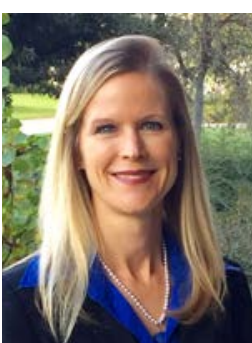

evident in her textbook, California Politics: A Primer, and she has a chapter in the APSA book, Teaching Civic Engagement: From Student to Active Citizen. Her scholarship on pedagogical practices has extended to research methods, online discussion forums, simulations, and internships. Van Vechten served as chair of the APSA Political Science Education Organized Section from 2013-2015. She was the section's program chair for the 2013 annual meeting, and has been a track moderator for the APSA Teaching and Learning Conference 20142016. Service to the association includes membership on awards committees and the Presidential Task Force on Technology (2015-2016), and helping to facilitate the transfer of sponsorship of the Journal of Political Science Education from the Organized Section on Political Science Education to APSA. Van Vechten is also active in the Western Political Science Association, having cochaired a conferencewithin-a-conference on teaching and learning $(2015,2016)$. She has received several teaching awards, including the Rowman and Littlefield Award for Innovative Teaching in Political Science (via APSA) in 2008.

\section{Continuing Council Members}

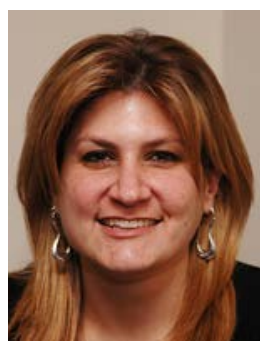

Roxanne L. Euben Wellesley College.

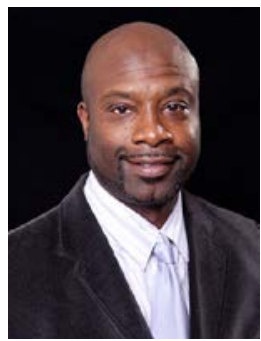

Byron D'Andra Orey Jackson State University

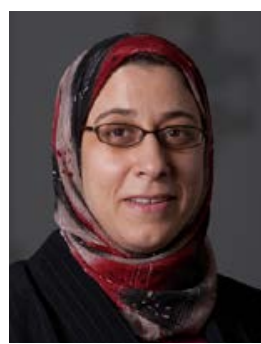

Amaney A. Jamal Princeton University

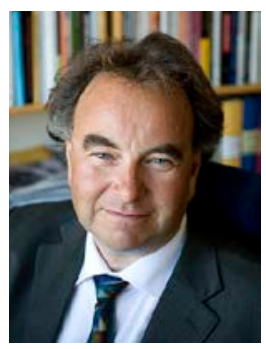

Bo Rothstein University of Gothenburg, Sweden

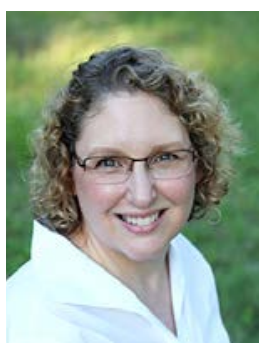

Brett Ashley Leeds Rice University

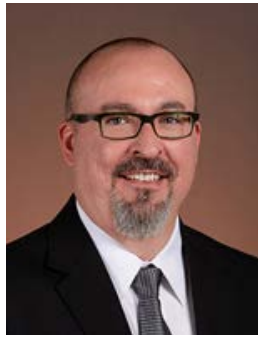

Cameron G. Thies Arizona State University

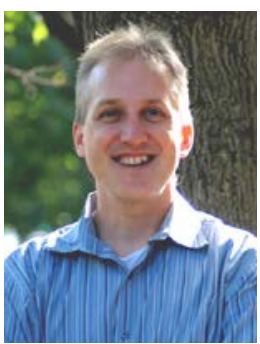

James Mahoney Northwestern University

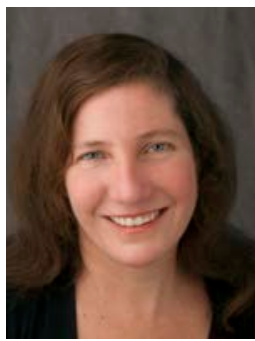

Caroline Tolbert University of Iowa 